\title{
Does it pay to acquire private firms? Evidence from the U.S. banking industry
}

\author{
by \\ George N. Leledakis* \\ Department of Accounting and Finance \\ School of Business \\ Athens University of Economics and Business \\ Greece \\ Emmanuel C. Mamatzakis \\ Department of Management \\ Birkbeck College \\ University of London \\ U.K. \\ Emmanouil G. Pyrgiotakis \\ Essex Business School \\ University of Essex \\ U.K. \\ and \\ Nickolaos G. Travlos \\ ALBA Graduate Business School at The American College of Greece \\ Greece and \\ Surrey Business School \\ University of Surrey \\ U.K.
}

This version: July 2020

\footnotetext{
* Corresponding author: Department of Accounting and Finance, School of Business, Athens University of Economics and Business, 76 Patission Str., 104 34, Athens, Greece; Tel.: +30 2108203459 . E-mail addresses: gleledak@aueb.gr (G. Leledakis), e.mamatzakis@bbk.ac.uk (E. Mamatzakis), e.pyrgiotakis@essex.ac.uk (E. Pyrgiotakis), n.travlos@surrey.ac.uk (N. Travlos). We would like to thank two anonymous referees, and the participants at the 2017 National Conference of the Financial Engineering \& Banking Society (FEBS), the 2018 ATHENIAN Policy Forum (APF) Conference, and the 2019 International Conference of the Financial Engineering \& Banking Society (FEBS) for their valuable comments and suggestions. George Leledakis greatly acknowledges financial support received from the Research Center of the Athens University of Economics and Business (EP2556-01). Nickolaos Travlos greatly acknowledges financial support from the Kitty Kyriacopoulos Chair in Finance. All remaining errors and omissions are our own.
} 


\title{
Does it pay to acquire private firms? Evidence from the U.S. banking industry
}

\begin{abstract}
We extend the U.S. bank M\&As literature by examining bidder announcement abnormal returns in deals involving both public and private targets over a 32-years examination period. Our main findings document the existence of a listing effect in our sample. Banks gain when they acquire private firms and lose when they acquire public firms. Gains in private offers are even higher when bidders employ financial advisors, whereas the opposite is true for public deals. We argue that this adverse advisor effect relates to the different levels of information asymmetry between public and private targets. Our results remain robust when we control for usual determinants of bidder abnormal returns, such as the method of payment, size, or relative size and when we control for sample selection and endogeneity problems.
\end{abstract}

JEL Classification: G14, G21, G34

Keywords: Mergers and Acquisitions, Banks, Listing Effect, Financial Advisor 


\section{Introduction}

The U.S. banking industry has experienced intense consolidation in the previous decades. Financial innovation and deregulation fostered successive waves of bank mergers and acquisitions (M\&As). To date, empirical research fails to provide conclusive evidence that the U.S. bank mergers create value for the bidding firms' shareholders. Cornett and De (1991), Houston and Ryngaert (1994), DeLong (2001), DeLong and DeYoung (2007), Brewer and Jagtiani (2013), among others, find that bidding banks experience negative or insignificant abnormal returns around the merger announcement date. Empirical research on the nonfinancial M\&As documents similar results. However, there is also considerable evidence in the non-financial mergers showing that acquirers gain when they buy private firms and lose when they buy public firms (Chang, 1998; Fuller et al., 2002; Officer et al., 2009; Netter et al., 2011; Arikan and Stulz, 2016; Brander and Egan, 2017). This phenomenon is usually referred to as the "listing effect" (Faccio et al., 2006), and many studies investigate this issue in the context of information asymmetry theory (for an insightful summary see Tanna and Yousef, 2019).

In the case of M\&As, information asymmetry can be two-sided, since both bidders and targets may have private information on their own firm value (Eckbo, 2009). Bidders can limit the degree of asymmetric information regarding their value by paying with cash (Eckbo et al., 1990), while target information asymmetry can be mitigated in various ways. In particular, bidding firms may pay a lower purchase price to avoid the risk of inaccurately valuing the target (Makadok and Barney, 2001), or they might choose to pay with stock to share with the target firms' shareholders the risk of target overvaluation (Hansen, 1987; Finnerty et al., 2012).

An additional way to limit the amount of the asymmetric information regarding the target firms' value is using financial advisors (Officer, 2007). In fact, the choice of a financial advisor benefits bidders most when target information asymmetry is high (Graham et al., 2017). Financial advisors use their expertise in order to collect superior information for the potential 
targets and locate any synergetic benefits (Servaes and Zenner, 1996). This superior information should benefit bidders, as it reduces the search costs associated with finding the most valuable target (Kesner et al., 1994). These search costs are higher in private offers than in public offers, due to the differences in information availability between the two types of targets (Capron and Shen, 2007). By contrast, advisory fees are lower in acquisitions of private targets compared to public targets (Golubov et al., 2012). Building on these arguments, it is likely that there will be a positive (negative) trade-off between search costs reduction and advisory fees in private (public) offers. Therefore, if the market prices this trade-off at the announcement date, it is likely to find a positive (negative) relationship between financial advisor use and abnormal returns in acquisitions of private (public) targets. ${ }^{1}$

The aim of this paper is twofold. First, we examine whether there is listing effect in our sample of banking acquisitions. Second, we investigate whether and to what extent the use of financial advisors can explain the difference in market reaction between public and private offers. To address our research questions, we use a large and comprehensive sample of 2,008 completed M\&As of public and privately held targets by U.S. banks, announced between 1984 to 2015. At the univariate level, our findings indicate the existence of a listing effect in our sample. In addition, we find that bidders of private targets experience positive announcement abnormal returns when they choose to employ a financial advisor, while in public deals, the use of a financial advisor is associated with negative abnormal returns.

We conduct regression analysis to account for any confounding effects that may impact our results. Particularly, we control for method of payment, and other possible determinants of bidder gains such as size, and pre-merger performance. We also control for bidder-specific heterogeneity by adding bidder fixed effects in our regressions (Golubov et al., 2015).

\footnotetext{
${ }^{1}$ An alternative explanation, suggested by an anonymous reviewer, could be that the market perceives that bidders' stock is overvalued when they employ financial advisors in pursuing acquisitions of public targets. This issue leaves an open question for future research.
} 
Collectively, the results support our conjecture that the use of financial advisor relates to higher bidder abnormal returns in acquisitions of private targets. Interestingly, this positive advisor effect is stronger for deals advised by less prestigious advisors. This finding is consistent with our expectations, as non-top-tier advisors tend to charge lower fees for their services (Golubov et al., 2012). Hence, employing a less prestigious advisor in a private offer may result in a more positive trade-off between search costs reduction and advisory fees.

We employ two robustness checks to alleviate any endogeneity concerns. First, we use the propensity score matching approach, to examine whether selection bias could explain the listing effect in our sample. Second, we also account for the endogenous nature of the financial advisor choice using the two-stage procedure of Heckman (1979). We find that self-selection is not a major concern in our sample, which indicates that our baseline regressions provide reliable estimates.

Finally, we explore whether other potential explanations for the listing effect, reported in non-financial M\&As, may impact our results. More precisely, we test for the liquidity discount in private offers (Officer, 2007), the improved corporate governance of the post-crisis period (Alexandridis et al., 2017), or the monitoring hypothesis (Chang, 1998). We do not find evidence consistent with these explanations.

Our study is related to the extensive literature on the listing effect on non-financial U.S. mergers (Chang, 1998; Fuller et al., 2002; Netter et al., 2011, Arikan and Stulz, 2016). We apply a similar process in a different context- M\&As by U.S. banking firms. We focus our interest on the banking industry for two reasons. First, the majority of U.S. bank M\&As involves unlisted targets. Second, the valuation of private banks is subject to severe information asymmetries (Flannery et al., 2004). Our findings point out a significant difference in market reaction between public and private bids. Our explanation for this phenomenon is based on the theory of asymmetric information, and particularly, on the financial advisors' ability to provide 
acquiring firms with an information advantage in acquisitions of private targets. It appears that the use of financial advisor is a strong determinant of bidder gains in private offers, finding which contradicts the conventional wisdom that banks lose upon the announcement of a merger (Houston and Ryngaert, 1994; DeLong, 2003; Gupta and Misra, 2007; Brewer and Jagtiani, 2013).

The remainder of the paper is organized as follows. Section 2 reviews the related literature. Section 3 details the data collection for the empirical analysis. Sections 4 present our main empirical results. Section 5 deals with endogeneity issues, and Section 6 presents additional robustness checks. Section 7 concludes the paper.

\section{Theoretical framework and motivation}

\subsection{Listing effect and information asymmetry}

There is a wide literature in the non-financial M\&As, which examines the relationship between bidder returns, and the target firms' listing status (Chang, 1998; Fuller et al., 2002; Moeller et al., 2004; Faccio et al., 2006; John et al., 2010; Netter et al., 2011; Arikan and Stulz, 2016; Brander and Egan, 2017). Collectively, these studies document that in public offers, acquiring firm realize negative, or at best zero announcement abnormal returns, while in private offers abnormal returns are positive. The relevant literature attempts to explain this phenomenon under the asymmetric information perspective (Officer et al., 2009).

Information asymmetry is associated with the degree of information availability (Luypaert and Van Caneghem, 2017). In an M\&As transaction, information asymmetry can be two-sided, because both the bidder and the target may have information regarding their valuation that they do not convey to the other party (Hansen, 1987). One possible way to resolve this information asymmetry problem is to choose the appropriate method of payment (Eckbo et al., 1990). In fact, bidders who pay in cash avoid their misevaluation of their own stock, while bidders who 
pay with stock may reduce the cost of overpayment arising from the lack of information regarding the target firm's value (Eckbo, 2009).

The effect of bidder information asymmetry on announcement period returns is based on the overvaluation hypothesis of Leland and Pyle (1977) and Myers and Majluf (1984). According to this hypothesis, managers of acquiring firms will be inclined to pay with stock only if they believe that their firm is overvalued. Therefore, equity payments send a negative sign to the market regarding the acquiring firm's valuation, which translates to negative abnormal returns (Travlos, 1987). However, the relative degree of information asymmetry between the acquiring and the target firm may also have an impact on merger gains (Finnerty et al., 2012). In the case of private offers for example, target information asymmetry is expected to be high, as privately-owned firms disclose less information to the markets (Reuer and Ragozzino, 2008; Tanna and Yousef, 2019). To account for this information unavailability, acquiring firms could force private targets to accept a discount in the offer premium (Makadok, and Barney, 2001). Alternatively, acquiring firms may choose to pay with stock to mitigate information asymmetry regarding the target firm's valuation. In fact, evidence along these lines shows that in private offers, stock payments are associated with higher abnormal returns (Chang, 1998; Fuller et al., 2002; Netter et al., 2011).

\subsection{Financial advisors and information asymmetry}

In the context of information asymmetry theory, we propose that the use of financial advisor might help bidding firms alleviate concerns regarding the target firms' valuation. Officer (2007) argues that financial advisors may limit the amount of target information asymmetry for bidding firms. Based on this argument, we expect the advisor effect to be more pronounced in private offers relative to public ones since target information asymmetry is higher in the former deals relative to the latter ones. Private firms have more control over the information they convey to the market, whereas for public targets, the market for corporate control serves 
as an asset valuation and information-processing mechanism (Capron and Shen, 2007). In addition, high target information asymmetry in private offers creates more opportunities for bidders to use superior information and exploit synergetic benefits (Makadok and Barney, 2001). Financial advisors, as experts in information processing, may be more capable in identifying such synergetic benefits, rather than the bidding firm alone. By contrast, exploiting superior information in public offers is less likely, since information on public firms is widely available due to regulatory disclosure requirements, analysts' coverage and press releases (Feito-Ruiz et al., 2014).

There are several studies that examine the relationship bidder gains and financial advisors under the information asymmetry perspective. In their early study, Servaes and Zenner (1996) found that financial advisors are used in more complex transactions that are characterized by significant asymmetric information. On this end, acquirers of more opaque targets experience a larger fraction of total acquisition gains, since they obtain superior information regarding the target firm's value during the due diligence process (Graham et al, 2017). Furthermore, Chemmanur et al. (2019) indicate that this positive advisor effect in announcement abnormal returns is more pronounced in more complex and opaque industries.

Another strand of the literature focuses on the advisors' reputation in explaining announcement abnormal returns. Ismail (2010) suggests that acquiring firms garner higher abnormal returns when they employ non-top-tier financial advisors, rather than large prestigious investment banks. By contrast, Golubov et al. (2012) document a positive relationship between advisor reputation and bidder CARs, after controlling for sample selection bias issues.

Overall, there is a plethora of studies examining either the listing effect on M\&A deals, or the financial advisor effect on bidder abnormal returns. Yet, to the best of our knowledge, there is no evidence on the role of financial advisors in explaining the different market reaction 
between public and private offers. In this study, we fill this gap by documenting an adverse advisor effect across the two types of deals, and we link this finding to the theory of asymmetric information.

\section{Sample description and statistics}

\subsection{Merger sample}

We collect merger data from Thomson ONE database. Our sample consists of all completed M\&As by U.S. banking firms, with initial bids announced between January 1, 1984 and December $31,2015 .^{2}$ We retrieve mergers that meet the following criteria:

1. Bidding firms are commercial banks with a three-digit primary SIC code equal to 602, or bank holding companies with a four-digit primary SIC code equal to 6712 .

2. The bidder is publicly traded. The target is either a public firm or a private firm.

3. All public firms are listed on NYSE, Amex, or Nasdaq.

4. Bidding firms have available return data on the Center for Research in Security Prices (CRSP) for at least five days around the merger announcement and COMPUSTAT data for the year-end prior to the merger announcement.

5. The bidder acquired an interest of above $50 \%$ in the target firm, raising its interest from below $50 \%$ to above $50 \%$.

6. The deal value is disclosed and above $\$ 1$ million.

The above selection process results in an initial sample of 2,139 M\&As, where 817 of the targets were listed, and 1,322 were stand-alone private companies. We follow Fuller et al. (2002) and we exclude from the sample 103 clustered mergers, where the bidding bank acquired more than one target firms within 5 days, in order to isolate the bidder's abnormal return for a specific merger ( 24 public targets, and 79 private targets). We further eliminate 5 duplicate listings from the sample (1 public target, 4 private targets). Duplicates are defined as instances where the same bidder, target and announcement date are listed more than once in the Thomson ONE database. ${ }^{3}$ Similar to Hagendorff and Vallascas (2011), we also exclude 17

\footnotetext{
${ }^{2}$ Barnes et al. (2014) suggest that Thomson ONE data (former SDC) are reliable from 1984 and onward while early 1980s are not recommended for research.

${ }^{3}$ Duplicates emerge from errors in updating Thomson ONE data. In these cases, when new information is available for a M\&A transaction, a new record is created in the database while the previous one still exists.
} 
mergers which involved failing institutions, as reported by Thomson ONE (2 public targets, and 15 private targets). Finally, we exclude 6 mergers where data for the method of payment are not available (6 private targets). Our final sample consists of 2,008 mergers, where 790 of the targets were listed firms, and 1,218 were private firms.

\subsection{Sample statistics}

Table 1 shows the inflation-adjusted (base 2015 dollars) mean value of transaction and the number of mergers per year. The merger sample is segmented based on the target firm's listing status. Both the number and the size of M\&As do not increase monotonically through time. Initially, we observe a sharp increase in merger activity in the 1990s, for both types of mergers. This increase is consistent with Mitchell and Mulherin (1996), who document that the deregulation wave of the 1990s has spurred intense consolidation in the U.S. banking industry. In the new millennium, merger activity experienced a downward trend, and did not peak until the mid-2000s. Further, the 2008 financial crisis led to a dramatic decrease in the level of bank M\&As. However, in the most recent years, bank merger activity exhibits an increasing trend, following the passage of the Dodd-Frank Act (Leledakis and Pyrgiotakis, 2019).

\section{Insert Table 1 here}

Table 2 reports the distribution of our merger sample by target firm's industry affiliation, using 48-industry classifications from Fama and French (1997). Industries definitions are based on the four-digit primary SIC codes. ${ }^{4}$ We report by industry the number of banks making successful bids for all types of targets, and we further divide the sample based on the target firm's listing status. As expected, almost the entire sample (98.95\%) involves targets within the financial industry, whereas most deals (90.04\%) concern bank-to-bank mergers.

\section{Insert Table 2 here}

\footnotetext{
${ }^{4}$ Primary SIC codes denote the primary line of business for a company. However, up to ten different SIC codes may be assigned to each firm, based on the lines of business the company is involved. Therefore, a target firm in our sample may be characterized a bank by its primary SIC code, but it could also engage in trading, insurance, or real estate activities.
} 
Table 3 provides additional data describing the sample. All variables are defined in the Appendix. Panel A of Table 3 reports the mean and median (in brackets) values for bidderspecific characteristics. In line with the literature on non-financial M\&As, the average bidder size in public offers is larger compared to the corresponding figure in private offers, both in terms of total assets and market value of equity. Further, profitability and equity capitalization do not differ across the two subsamples, where bidders of private offers appear to have higher idiosyncratic return volatility.

Panel B of Table 3 reports the mean and median values for the deal-specific characteristics of our sample. Not surprisingly, the dollar value of M\&As is much larger for listed targets than for private targets. In fact, mergers involving public targets are approximately 22 times larger compared to those involving private targets. As a result, the relative size of target to bidder is significantly higher in public offers. Days to completion serves as a proxy for merger complexity (Becher and Campbell, 2005). The length of a merger is larger for public than for private offers, suggesting that public deals are more difficult to complete. Following Martin (1996), we group the method of payment into three different categories: (1) cash, (2) stock, and (3) combination of cash and stock. ${ }^{5}$ We observe that stock financing is the prevailing method of payment for acquisitions of public and private targets. However, bidders in private offers use significantly more cash to pay for the acquisition compared to bidders in public deals. Finally, banks that buy private firms focus more in intrastate transactions and use the pooling accounting method less often to incorporate the target in their books relative to those buying public firms.

To address our research question, we report financial advisor data for the bidding banks of our sample. We collect information, from Thomson ONE database, on whether any advisors

\footnotetext{
${ }^{5}$ Cash payments include combinations of cash, debt, or liabilities. Stock payments include financing with common stock or combinations of common stock and options or warrants. Combo financing includes combinations of cash, common stock, debt, preferred stock, convertible securities and methods classified as "other consideration" by Thomson ONE database.
} 
were used by the bidding firm, number of advisors used and advisor's full name. From our entire sample of 2,008 M\&As, we identified 983 mergers with complete information about bidder financial advisors (540 public targets, and 443 private targets). Out of the 983 sampled deals, 796 were advised by at least one investment bank, and 187 deals did not involve any financial advisors on the part of the bidder (in-house deals).

We also control for the financial advisor's reputation, to test whether top-tier investment banks are perceived to provide better services in bank acquirers than non-top-tier advisors. Hence, we download financial advisors league tables from Thomson ONE database for deals announced and completed during the period January 1984 to December 2015. The rankings are based on the dollar value of transaction handled by the advisor during the sample period. Interestingly, the top-11 advisors are the same in both announced and completed deals' rankings. Following Fang (2005), we classify advisors into two tiers: the top-8 investment banks are defined as "top-tier" and all other financial advisors as "non-top-tier". The top-8 financial advisors are Goldman Sachs \& Co, Morgan Stanley, Bank of America Merrill Lynch, JP Morgan, Citi, Credit Suisse, Barclays, and Lazard. Most of these investment banks appear in league tables of prior studies (Rau, 2000; Hunter and Jagtiani, 2003; Golubov et al., 2012). Hence, we suggest that financial advisors' reputation is relatively stable overtime.

In order to correctly assign the reputation of each financial advisor, we follow Golubov et al. (2012), and we account for the M\&As between financial advisors. For example, Bank of America was not a top-tier financial advisor prior to the acquisition of Merrill Lynch in 2008. Hence, mergers advised by Bank of America before 2008 are classified as advised by a nontop-tier financial advisor. Finally, in case a bidding bank had employed multiple financial advisors, the deal is classified as advised by a top-tier advisor if at least one of the advisors belongs to the top-8 group (Servaes and Zenner, 1996).

\section{$\underline{\text { Insert Table } 3 \text { here }}$}




\section{Main empirical results}

\subsection{Univariate analysis}

As a first step in our empirical analysis, we use the standard event study methodology, outlined by Brown and Warner (1985), to evaluate bidder gains around the merger announcement dates. We estimate cumulative abnormal returns (CARs) over a five-day event window, centered on the announcement date $(-2,+2)$ using the market adjusted return model: ${ }^{6}$

$$
A R_{i, t}=R_{i, t}-R_{m, t}
$$

where $R_{i, t}$ is the return for stock $i$ on day $t$ and $R_{m, t}$ is the market return on the CRSP NYSE/Amex/Nasdaq value-weighted index on day $t$. We prefer to follow this approach rather than estimating market model parameters over a time interval prior to the merger announcement. This enables us to account for the possibility that a bidding bank had announced another merger at some point during the estimation period (Fuller et al., 2002). ${ }^{7}$ We evaluate the statistical significance of our results based on the standardized cross-sectional test of Boehmer et al. (1991). This procedure corrects for potential increases in the variance of abnormal returns, commonly found in event studies.

Panel A of Table 4 presents the mean CARs for bidding banks classified by the target firm's listing status. For the entire sample of 2,008 deals, bidder abnormal returns are negative $(-0.22 \%)$ and statistically significant at the one percent level. In public offers, bidders realize negative CAR of $-1.45 \%$, statistically significant at the one percent level, a finding which is consistent with prior empirical work (Cornett and Tehranian, 1992; DeLong and DeYoung, 2007; Brewer and Jagtiani, 2013). By contrast, in private offers, bidding banks generate a mean

\footnotetext{
${ }^{6} \mathrm{We}$ also examined other event windows frequently used in the literature $(-1,+1),(-5,+1),(-10,+1),(-1,+10)$, $(-10,+10),(-20,+20)$. Results remained qualitatively similar.

7 To ensure robustness of our results we have also estimated CARs using the market model and the mean adjusted returns model. Results remained unchanged.
} 
abnormal return of $0.57 \%$, which is statistically significant at the one percent level. The difference in mean CARs between the two types of deals is also statistically significant at the one percent level. This result indicates the existence of a listing effect in our sample.

\subsubsection{Method of payment and bidder CARs}

Panel B of Table 4 presents the mean CARs for bidding banks classified by the target firm's listing status and method of payment. For the entire sample, the use of cash is associated with insignificant abnormal returns, whereas deals financed by pure stock or a combination of cash and stock realize negative and statistically significant, at the one percent level, abnormal returns. In public bids, abnormal returns for cash offers are again indistinguishable from zero. However, in stock or combination offers, abnormal returns are negative $(-1.61 \%$ and $-1.63 \%$, respectively) and statistically significant at the one percent level. Therefore, in public bank M\&As, the use of equity is associated with negative market reaction, consistent with the corresponding evidence from non-financial M\&As (Travlos, 1987). On the contrary, in private offers, bidder abnormal returns are positive and statistically significant at the five percent level regardless of the method of payment: cash $(0.60 \%)$, stock $(0.56 \%)$, and combination $(0.57 \%)$. In addition, all differences between private and public bids are positive and statistically significant at the ten percent level, or better, which suggests that the former deals outperform the latter ones in all cases.

\subsubsection{Financial advisors and bidder CARs}

Panel C of Table 4 presents bidder CARs for the subsample of 983 deals where data on financial advisors are available on Thomson ONE database. We split the sample based on whether the bidding banks has employed at least one financial advisor (advisor), or not (inhouse). Initially, the results are consistent with Servaes and Zenner (1996) who find that the use of a financial advisor does not affect announcement abnormal returns. Bidder CARs are 
negative and statistically significant at the five percent level or better in both types of deals: advisor $(-0.59 \%)$, in-house $(-0.56 \%)$.

When we breakdown the sample according to the target firms' listing status, we extract different results. In fact, we observe an adverse advisor effect on bidder CARs between public and private offers. In public offers, in-house deals experience insignificant abnormal returns, whereas advised deals realize negative abnormal returns in the order of $-1.90 \%$, statistically significant at the one percent level. By contrast, in private offers, bidder CARs for in-house deals are negative $(-0.61 \%)$ and statistically significant at the ten percent level, while CARs for advised deals are positive (1.47\%) and statistically significant at the one percent level. It is also noteworthy that for in-house deals, the mean difference between private and public offers is not significant at conventional levels, and thus it is the only subsample where we do not report a listing effect. When advisors are used, however, private bids outperform public bids by as much as $3.37 \%$. The difference between the two types of deals is statistically significant at the one percent level.

The results of this analysis provide some interesting insights. It appears that the use of financial advisor is negatively related to bidder abnormal returns in public offers, whereas the opposite is true for private offers. We attribute this adverse effect to the different level of information asymmetry between the two types of target firms. The relevance on asymmetric information in our setting is based on the fact that financial advisors are able to obtain information beyond the reach of the bidding firms (Chahine and Ismail, 2009). More precisely, one of the benefits of using financial advisors in mergers, is their ability to reduce search costs by matching bidding and target firms (Kesner et al., 1994). In theory, therefore, financial advisors can save money for the bidding firms. In practice however, the bidding firms' net benefit should depend on the relative trade-off between search costs reduction and advisory 
fees. More importantly, the direction of this trade-off would vary across deals involving private or public targets.

As outlined by Capron and Shen (2007) bidders in private offers incur higher search costs compared to public deals, due to the lack of widely-available information. In addition, advisory fees in private offers tend to be lower than in public deals (Golubov et al., 2012). Taken together, both arguments imply that the trade-off between search costs reduction and advisory fees should be more lucrative in private than in public offers, as biddings firms pay less and realize higher reduction in search costs.

\section{Insert Table 4 here}

\subsection{Multivariate analysis}

The findings of the previous subsection provide an interesting input for a more in-depth analysis of the significant difference in CARs between private and public bids. However, these univariate comparisons may be misleading as they do not account for any potential confounding effects. For instance, if bidders who employ advisors in public deals are more likely to use stock, then the negative advisor effect might reflect a method of payment effect. For this reason, we should control for these potentially confounding effects, in order to isolate the net effect of financial advisors on bidder CARs. To do so, we conduct several ordinary least squares (OLS) regressions, where the dependent variable is the five-day bidder CARs centered on the announcement date. In our regressions, we include two different types of covariates: (1) bidder-and deal-specific characteristics, and (2) financial advisor data. We run two regressions for our entire sample, as well as for the subsamples of public and private deals (one without financial advisor data and one with financial advisor data).

To ensure that the existence of outliers do not influence our results, we winsorize all the continuous variables at $1 \%$ and $99 \%$ level. Further, we control for heteroskedasticity by estimating robust standard errors, following White (1980). Correlation coefficients of the 
independent variables indicate a weak to moderate degree of linear relationship among the several sets of variables. ${ }^{8}$ Finally, we also include year fixed effects in all our regressions.

\subsubsection{Regression analysis results}

Table 5 presents the results of our regression analysis. The first 2 columns report results for the entire sample. First and more importantly, the coefficient of Private is positive and statistically significant at the one percent level in the first two models. The magnitude of its coefficient is $1.5 \%$ in model 1 and $2.0 \%$ in model 2 , which suggests that the listing effect is robust to the inclusion of all types of variables. In other words, private bids outperform public offers, even when we account for factors such as size, method of payment, or advisor use.

A handful of the remaining control variables bear statistically significant coefficients in our regression models. In model 1 the coefficients of Cash and Stock are both positive and statistically significant at the ten percent and five percent level, respectively, suggesting that all-cash and all-stock offers experience higher abnormal returns compared to mixed offers. However, in model 2 only Stock remains statistically significant at the ten percent level. Relative size in model 1 is also negative and statistically significant at the five percent level, but it loses significance as financial advisor variables are included in the analysis. In model 1, consistent with Officer et al. (2009), Sigma has a positive effect on bidder CARs, statistically significant, at the one percent level. In unreported results we also included an interaction term of Sigma with Stock, with no substantive changes in our results. ${ }^{9}$ The negative coefficient of Pooling, statistically significant at the one percent level, indicates that when bidding banks use the purchase method, they experience larger abnormal returns. In model 2, both Advisors and Top-tier are insignificant at conventional levels. These results are in line with Servaes and Zenner (1996), Rau (2000), Hunter and Jagtiani (2003), and Ismail (2010). Their results suggest

\footnotetext{
${ }^{8}$ The highest correlation coefficient between continuous variables is 0.45 (in absolute terms) between Bidder size and Sigma.

${ }^{9}$ Moeller et al. (2007) find a negative relationship between bidder CARs in public bids financed with stock and bidder idiosyncratic volatility.
} 
that neither the use of an advisor nor advisor reputation have any significant effect on announcement abnormal returns.

Models 3 and 4 report regression results for the subset of publicly traded targets. At first, the coefficients of Cash and Stock are similar to those reported for the entire sample. Relative size is negative and statistically significant, at the five percent level, in model 3, suggesting that abnormal returns decrease when the target is larger relative to the bidder (Jensen and Ruback, 1983; Travlos, 1987). Pooling has a negative and statistically significant, at the one percent level, coefficient in both models 3 and 4, implying that the purchase method is preferable in public bids. Interestingly, Advisors enters the regression with a negative and statistically significant coefficient, at the five percent level, in model 4. The magnitude of its coefficients indicates that in public offers, bidders who use financial advisors experience $-1.7 \%$ lower abnormal returns than bidders of in-house deals. Top-tier is insignificant at conventional levels, which suggests that the advisor reputation does not have an effect on bidder CARs (Ismail, 2010).

Models 5 and 6 report results for the acquisitions of private targets. In model 5, only Sigma is significant at the ten percent level, which suggests that bidder-and deal-specific characteristics are not strongly related to abnormal returns in private offers. This might reflect the difficulty of investors to price a deal that involves a difficult to value private target. Consequently, this difficulty may justify the significant role of financial advisors in explaining bidder CARs. In fact, Sigma loses significance when we add financial advisor data in model 6, whereas Advisors enters the regression with a positive and statistically significant coefficient at the one percent level. This finding indicates that the use of financial advisors is beneficial to the bidding firms, probably due to their ability to access and evaluate information in private offers, which are characterized by high information asymmetry. Therefore, the results of our 
cross-sectional regressions are consistent with our univariate results, which suggest an adverse advisor effect between public and private bids.

Finally, our results do not support the argument that geographical focus is strong determinant of bidder CARs in bank M\&As (Houston and Ryngaert, 1994; DeLong, 2001). In fact, State is positive but statistically insignificant, at conventional levels, in all six models. Consistent with Becher and Campbell (2005), we do not find any empirical support that prior bidder performance $(R O A)$, affects merger gains. Lastly, the explanatory power of all our models is relatively low, since the Adjusted $\mathrm{R}^{2}$ ranges from $6.2 \%$ to $13.1 \%$. Nonetheless, this finding is typically observed in regressions of bidder CARs (Fuller et al., 2002; DeLong, 2003; Moeller et al., 2004).

\section{$\underline{\text { Insert Table } 5 \text { here }}$}

\subsubsection{Bidder fixed effects models}

Thus far, we have identified that when banks acquire private firms, they experience positive announcement abnormal returns. In addition, banks that use financial advisors in private offers realize even higher announcement abnormal returns. However, it is possible that there could be a time-invariant bidder-specific driver of acquisition success that can better explain this pattern in abnormal returns. To control for these unobserved characteristics, we rerun the baseline regression models for the full sample with the inclusion of bidder fixed effects as in Golubov et al. (2015). Bidder fixed effects allow us to control for this unobserved heterogeneity across bidding firms, and thus, we can extract more robust inferences regarding the advisor effect on bidder CARs.

Models 1 and 2 of Table 6 replicate the first two models of Table 5 with the addition of bidder fixed effects. As these models show, Private is positive and statistically significant at the one percent and five percent level, respectively, which suggests that even after controlling for the unobserved heterogeneity across biding banks, private offers still outperform public 
deals. In model 1, Cash and Stock are both positive and statistically significant at the one percent level. However, in model 2, when we add financial advisor variables, only Cash remains statistically significant at the five percent level. In all models of Table 6, Cash bears a positive and statistically significant coefficient at the ten percent level or better, which is consistent with a strongest positive signal conveyed to the market by the use of cash. Results for Relative Size and Pooling are similar to the ones reported in the baseline regressions of Table 5. In model 2, Occasional is also positive and statistically significant at the one percent level, indicating that more active bidders tend to perform better in terms of abnormal returns. Again, both Advisors and Top-tier have an insignificant effect on bidder CARs for the entire sample. Notably, the inclusion of the bidder fixed effects increases substantially the explanatory power of our baseline regression models, since the Adjusted $\mathrm{R}^{2}$ is now $22.1 \%$ in model 1 and $24.2 \%$ in model 2 , respectively.

Next, we also investigate the advisor effect on bidder CARs between public and private bids. To fully capture this effect, we create four mutually exclusive interaction variables in the spirit of Masulis et al. (2007): Private $\times$ Advisors, Private $\times$ In-house, Public $\times$ Advisors, and Public $\times$ In-house (the omitted interaction variable). Model 3 of Table 6 presents the results of this analysis. In line with our previous findings, the coefficient for Private $\times$ Advisors is positive and statistically significant at the five percent level, while the coefficient for Public $\times$ Advisors is negative and statistically significant at the five percent level. Therefore, the adverse effect of financial advisors on bidder CARs prevails, even when we control for the bidderspecific unobserved heterogeneity.

Finally, we also analyze the effect of advisor reputation on bidder CARs. To do so, we focus on the subsample of 796 deals, where at least one advisor was employed by the bidding bank (we thus exclude the 187 in-house transactions). In addition, we create four mutually exclusive interaction variables: Private $\times$ Top-tier, Private $\times$ Non-top-tier, Public $\times$ Top-tier, and Public 
$\times$ Non-top-tier (the omitted interaction variable). Model 4 of Table 6 presents the results of this analysis. The positive and statistically significant, at the ten percent level, coefficient of Private $\times$ Non-top-tier indicates that in private offers the positive advisor effect on bidder CARs comes from non-top-tier advisors. This evidence is consistent with the early studies of Michel et al. (1991) and McLaughlin (1992) who find that the use of less prestigious advisors is associated with higher announcement abnormal returns.

\section{Insert Table 6 here}

\section{Control for endogeneity}

Inferences from regression results in corporate finance studies may be spurious due to the presence of untreated endogeneity in the underlying data generating process. In fact, the above analysis assumes that the bidder's choice to acquire a private rather than a public firm is exogenously determined. However, there might be innate differences between bidders of public and private targets, which imply that the bidder's choice could be determined endogenously. Furthermore, the same endogeneity concern applies to the advisor choice. In this section therefore, we address both endogeneity issues using: (1) the propensity score matching approach, and (2) the Heckman's (1979) two-stage procedure.

\subsection{Propensity score matching and the listing effect}

As we have seen in the summary statistics, bidder- and deal-specific characteristics differ significantly between public and private offers. For instance, in private deals, bidders are significantly smaller, have higher idiosyncratic volatility, and use cash more frequently as the means of payment. All these characteristics are associated with higher announcement abnormal returns (Travlos, 1987; Moeller et al., 2004; Officer et al., 2009). Therefore, it is likely that the difference in CARs between private and public offers relates to these differences, and it is not a direct consequence of the target firms' listing status. On the one hand, using control variables in the cross-sectional regressions helps alleviating this problem. On the other hand, if the 
comparison groups have poor distributional overlap in their characteristics, then the linear regressions are not the optimal solution to capture the observed heterogeneity (Heckman et al., 1998). For this reason, we use the propensity score matching (PSM) approach, as in Alexandridis et al. (2017), and Leledakis and Pyrgiotakis (2019).

To implement our matching strategy, we run two probit models to estimate the probability of a deal to involve a private target (propensity score). The first model is for the entire sample of 2,008 observations and the second for the subsample of 983 where financial advisor information where available on Thomson ONE. ${ }^{10}$ In this empirical specification, private deals are the treated group, and public deals constitute the control group. Then, we estimate propensity scores for each model, and we use them to match our treated and control groups according to the nearest neighbor matching approach (one-to-one). ${ }^{11}$ Finally, we compute the difference in bidder CARs between treated and control groups. In the literature, this difference is presented as the average treatment effect on the treated (ATT).

The results of the probit models provide us with some interesting insights. As shown in Panel A of Table 7, there are several significant variables, statistically significant at the ten percent level or better, that determine the probability for a deal to involve a private target. More specifically, private deals are more likely to be financed by cash, and they are also less likely to be intrastate. Further, bidders of private targets are more likely to be smaller, and private targets also tend to be smaller relative to their bidders. Also, private deals need less time to be completed. Finally, the negative coefficient of Advisors, statistically significant at the one percent level, suggests that bidders in private offers employ financial advisors less often than bidders in public deals. The Pseudo $\mathrm{R}^{2}$ is $27.1 \%$ in model 1, and $29.7 \%$ in model 2 , respectively.

\footnotetext{
${ }^{10}$ Equity-to-assets is not used an independent variable in our probit models, since it worsens the quality of matching between private and public offers. Its exclusion ensures that our treated and control groups are adequately balanced in their covariates.

${ }^{11}$ Matching is done with replacement due to the limited number of control observations. For robustness, we have also more than one neighbors. Result remained similar.
} 
In Panel B of Table 7, we present the results for the ATTs. Apparently, bidder abnormal returns for private deals are higher than bidder CARs in PSM-matched public deals. When we do not account for financial advisors, the difference between private and PSM-matched public deals is $1.17 \%$, statistically significant at the five percent level. However, when we do account for financial advisors, the difference in CARs between private and PSM-matched public deals increases to $2.11 \%$, statistically significant at the one percent level. This finding is consistent with our prediction for the added value of advisors in private offers. Overall, unless there are important observable characteristics not included in the probit models, we can conclude that private offers outperform very similar public deals in terms of bidder CARs, and this outperformance is relatively robust to any observed heterogeneity issues.

\section{Insert Table 7 here}

\subsection{Controlling for endogeneity in the advisor choice}

It should be emphasized that the documented advisor effect on bidder CARs is based on two assumptions: (1) the bidders' choice to employ a financial advisor is exogenously determined, and (2) the bidders' choice to employ a top-tier financial advisor is exogenously determined. However, it is likely that there are some persistent bidder- and deal-specific characteristics that influence the choice to use a financial advisor, or the choice to use a top-tier financial advisor rather than a non-top-tier financial advisor. In this case, both choices could be correlated with certain bidder- and/or deal-specific characteristics, and as a result, our OLS regression models would produce spurious estimates. To address this sample selection issue, we employ Heckman's (1979) two-stage procedure, using the inverse Mills ratio.

To account for the endogenous nature of both the advisor choice and the advisor reputation, we implement this two-stage procedure two times. At first, we conduct the first-stage equation of the Heckman's procedure using a probit model. The dependent variable of this model equals one for deals where the bidder has employed at least one financial advisor, and zero for in- 
house transactions. From this stage, we construct the inverse Mills ratio that we add as an additional independent variable in the second-stage equation. In the second-stage equation, the dependent variable is the five-day bidder CARs, and the analysis is done only for the subsample of deals involving a financial advisor. Then, we repeat this analysis for the sample of the 796 deals where at least one advisor was used. In this case, the first-stage equation is a probit model, where the dependent variable equals one for deals advised by top-tier advisors, and zero for deals advised by non-top-tier advisors. Finally, the second-stage equation refers only to deals advised by top-tier advisors. The coefficients we obtain from both second-stage regressions are corrected for the sample selection bias (Doukas et al., 2014).

Table 8 presents the results for this analysis. According to the probit model 1, there are many variables that determine the acquirer's decision to employ a financial advisor. More precisely, larger, better-capitalized, and less profitable bidders are more likely to employ a financial advisor in their acquisitions. In addition, intrastate deals and deals that involve public targets are associated with higher probability of financial advisor use. In contrast, financing the deal purely with cash or stock translates to lower probability of financial advisor use. Relative size has a positive impact, statistically significant at the one percent level, on the bidders' choice to employ a financial advisor. Both Pooling and Occasional have negative coefficients, statistically significant at the five percent and one percent level, respectively. The Pseudo $\mathrm{R}^{2}$ of the first-stage equation indicates that our probit models explain up to $30.5 \%$ of the bidders' choice to employ a financial advisor in their acquisitions. Model 3 presents the results of the probit model for the advisor reputation. It appears that largest, less-capitalized banks who buy larger targets are more likely to employ a top-tier financial advisor. The Pseudo $\mathrm{R}^{2}$ of the firststage equation indicates that the model explains up to $33.5 \%$ of the bidder choice between a top-tier and a non-top-tier advisor. 
The most important part of this analysis derives from the second-stage equations. In fact, in both models 2 and 4, the coefficient of Inverse Mills ratio is statistically insignificant at conventional levels. This finding means the self-selection bias is not an issue in our sample, and as such, the regression coefficients in Tables 5 and 6 should be considered reliable. Therefore, we can conclude that the use of a financial advisor (and particularly a non-top-tier advisor) is associated with higher bidder announcement CARs in private offers.

\section{Insert Table 8 here}

\section{Additional robustness checks}

In the non-financial literature, there are several explanations for the higher bidder abnormal returns in private offers compared to public offers (Faccio et al., 2006; John et al., 2010). For this reason, we present various additional robustness tests to ensure the validity of our results. In particular, we examine whether other alternative explanations of the listing effect can influence our findings.

\subsection{Liquidity discount in acquisition premiums}

Officer (2007) suggests that the listing effect can be attributable to lower acquisition prices for private targets. More precisely, the author argues that due to liquidity constraints, acquisition premiums for private targets should be lower than for public targets. Consequently, lower premiums should result in higher bidder abnormal returns. To test this hypothesis, we obtain data on acquisition multiples (available for both public and private targets) from Thomson ONE database. In line with Gupta and Misra (2010), we use the ratio of deal value to the book value of target's equity. ${ }^{12}$ We are able to retrieve acquisition multiple data for 1,040 deals (762 public and 278 private).

\footnotetext{
${ }^{12}$ We also examine (but not report) the other 3 acquisition multiples outlined by Officer (2007) and find similar results.
} 
Panel A of Table 9 shows the mean value of our acquisition multiple for both public and private offers. First, we report raw multiple data, as obtained by the database. We observe that the values are similar to those reported by Gupta and Misra (2010), but the mean difference between the two types of deals is insignificant at conventional levels. However, as Officer (2007) indicates, inferences from comparing raw acquisition multiple data may be biased, due to the different characteristics between public and private offers. To address this issue, we employ the propensity score matching approach of Table 7 . This allows us to compute the difference in acquisition multiples between private offers and PSM-matched public deals. ${ }^{13}$ Our findings indicate that there are no significant differences in acquisition multiples between private and similar public deals. Therefore, these findings indicate that our results are less likely to be driven by acquisition discounts for private targets.

\subsection{Leakage of information}

In the M\&As literature, some authors suggest that merger gains may be capitalized before the official merger announcement. For example, Schipper and Thompson (1983) find significant bidder gains in the pre-acquisition period and attribute their findings to potential leakage of information. In this case, measuring abnormal returns at the announcement date may underestimate the market reaction for the transaction, since such leakage would show-up in the pre-announcement bidder returns. Hypothetically, this is a more likely scenario in deals than involve two listed firms, where information regarding the merging firms is more widely available. In that event, the documented listing effect on the merger announcement date may be overestimated, since merger gains for public offers might have been impounded in the stock price days before the official announcement. To account for this possibility, we examine if there is a run-up in the bidding firm's stock price, emanating from any potential leakage of

\footnotetext{
${ }^{13}$ Matching with replacement produces 146 matches. Our results remain similar if we match without replacement or if we use more than 1 neighbors in our matching approach.
} 
information regarding the acquisition. Following Faccio et al. (2006) we compute preannouncement abnormal returns over the window $(-15,-3)$, and we present the results in Panel B of Table 9. Over this interval, abnormal returns are positive for all types of mergers, but marginally significant only for the private offers. More precisely, bidder CARs are: $0.10 \%$ for public targets and $0.46 \%$ for private targets, and their difference is insignificant at conventional levels. Therefore, these results are inconsistent with the assumption that prior capitalization of merger gains account for the listing effect in our sample. ${ }^{14}$

\subsection{CARs at the completion date}

The literature on non-financial M\&As focuses almost exclusively on announcement period returns, a fact which implies that all expected price reactions should occur at the announcement of a bid. However, in practice, not all announced mergers are finally completed. An important feature of the financial sector is that regulatory approval is mandatory for the completion of a transaction. Regulators may reject an application if the acquisition does not satisfy the public benefit criteria, or exceed several concentration limits (Desai and Stover, 1985).

It is therefore likely that the probability of success may influence the market reaction upon the announcement of a proposed merger. In fact, the uncertain outcome may induce investors to postpone their reaction at a time where the bidder intention to acquire is indeed materialized. If the likelihood of an acquisition success is higher for private than for public targets, announcement abnormal returns in public bids could be downward biased. In this case, abnormal returns at the deal completion date may be higher for public than for private bids. Therefore, the listing effect could relate to the difference in the timing of the market reaction for the deal, rather than the listing status of the target firm.

\footnotetext{
${ }^{14} \mathrm{We}$ also examine deals that began as a rumor. Thomson ONE identifies a rumor for possible acquisition for 26 and 9 acquisitions of public and private targets, respectively. Given the small number of deals in each category, it is quite unlikely that rumors of acquisitions could explain the listing effect in our sample.
} 
In the spirit of Faccio et al. (2006), we examine the acquisition success rates for the different types of deals. To do so, we identify acquisitions that were announced as completed transactions at the initial announcement date. From our entire sample of 2,008 completed M\&As, only 65 deals where announced when completed (1 public target, and 64 private targets). Thus, for the remaining 1,943 deals there was uncertainty regarding the successful completion of the proposed transaction (789 public targets, and 1,154 private targets). Further, we find $199 \mathrm{M} \&$ As that were announced but not completed during the examination period (103 public targets, and 96 private targets). Accordingly, the acquisition success rate for a public bid is $(789 /(789+103))=88.45 \%$, while the acquisition success rate for a private bid is $(1,154 /(1,154+96))=92.32 \%$. Notably, the difference between the two proportion is statistically significant at the one percent level, using a Chi-square test $\left(\chi^{2}=9.25\right)$. This finding suggests that public deals are completed less often compared to private deals.

At last, we examine whether these differences in acquisition success rate translate into differences in bidder abnormal returns around the deal completion date. In line with announcement period returns, we estimate bidder CARs over a five-day window, centered on the completion date. We include in the analysis only the bidders of the 1,943 M\&As in which there was uncertainty about the acquisition success, and we present these results in Panel C of Table 9. In fact, CARs are positive for both types of mergers, but marginally significant only for public offers. More specifically, bidder completion CARs are: $0.32 \%$ for public targets and $0.10 \%$ for private targets. These results indicate that market participants do indeed reward bidding banks when they complete an acquisition of a public firm. However, the difference between the two types of deals is insignificant, suggesting that completion CARs do not offset the difference in announcement CARs between public and private bids. 


\subsection{Crisis effect on corporate governance}

In a recent study, Alexandridis et al. (2017) find that since 2010, the listing effect has been reversed in U.S. M\&As. In fact, the authors document that after the 2008 financial crisis, public offers generate comparable shareholder value to private ones. Further, they attribute these findings to the improvement of the corporate governance mechanisms.

Based on this argument, the listing effect in our case could reflect the fact that firms with better corporate governance tend to buy private firms. In that event, the difference in CARs between private and public bids is not a function of the target firm listing status. To test this prediction using the arguments of Alexandridis et al. (2017), we examine whether the listing effect in our sample has been reversed as a result of the recent financial crisis. We find that bidder CARs in both types of deals improve since 2010. However, the differences between public and private offers are statistically significant at the one percent level both in the pre2010 and the post-2009 periods (see, Panel D of Table 9). ${ }^{15}$ Therefore, even if corporate governance drives this improvement, the listing effect is still persistent in the acquisitions by U.S. banks.

\section{Insert Table 9 here}

\subsection{Limited competition for private targets}

One alternative explanation for the listing effect assumes limited competition for the privately held targets, due to the higher costs of obtaining accurate information. In a limited competition environment, bidders may realize positive abnormal returns, since the likelihood of underpayment is higher (Chang, 1998). In addition, James and Wier (1987), Cornett and De (1991), among others, document that the number of bids per target firm (proxy for competition) relates to statistically lower announcement returns, since the winning firm might overpay to win the bidding war. However, as shown in Table 3, most target firms receive only one public

\footnotetext{
15 The results are the same even if we start the examination period at 1990, as in Alexandridis et al. (2017).
} 
bid: public targets (98.10\%), and private targets (99.92\%). Hence, bidding banks face almost no competition in acquiring either public or private targets. It is therefore unlikely that the limited competition hypothesis can explain the listing effect in M\&As by U.S. banking firms.

\subsection{Monitoring hypothesis}

The monitoring hypothesis outlined by Chang (1998), suggests that when firms pay with stock in private offers, target firms' shareholders become effective monitors of the bidding firms' performance. Evidently, this explanation assumes that private firms are family-owned or closely held. However, in our sample, Thomson ONE reports only 3 cases where private target firms were family owned. ${ }^{16}$ It is therefore unlikely that the ownership structure of the target firm would have a monitoring effect in the case of M\&As by U.S. banks.

\section{Conclusion}

In this paper, we examine bidder abnormal returns in 2,008 completed M\&As of publicly traded U.S. banking companies announced between 1984 and 2015, as well as the differences in stock market reaction between public and private offers. Our findings indicate the presence of a listing effect in acquisitions by U.S. banks: bidder announcement CARs in acquisitions of privately held companies are significantly larger than in acquisitions of publicly traded firms. This listing effect persists through time and is robust to sample selection issues.

We interpret our results in the context of information asymmetry theory (Hansen, 1987). Officer et al. (2009) finds that when bidders pay with stock, they mitigate target information asymmetry, and thus, they enjoy higher announcement abnormal returns in difficult to value transactions. We extent this argument by hypothesizing that the use of financial advisors may also help bidding banks to extract superior information and realize merger-related synergies,

\footnotetext{
${ }^{16}$ A target is characterized as "family owned" if at least a family, a group of families, or a non-founding chairman controls $20 \%$ of the firm.
} 
especially in the case of private offers, where information regarding the target firm's value is limited. Our results document an adverse effect of financial advisors in public versus private offers. In fact, bidders gain when they employ advisors in acquisitions of private firms and lose when they do so in acquisitions of public firms. This differential advisor effect between the two types of deals holds even when we control for method of payment, and several bidder- and deal-specific characteristics that relate to bidder CARs. Finally, we document that the potential endogeneity of the advisor's choice does not impact our findings. 


\section{References}

Abadie, A., and G. W. Imbens. 2006. "Large Sample Properties of Matching Estimators for Average Treatment Effects." Econometrica 74: 235-267.

Alexandridis, G., N. Antypas, and N. G. Travlos. 2017. "Value Creation from M\&As: New Evidence." Journal of Corporate Finance 45: 632-650.

Arikan, A. M., and R. M. Stulz. 2016. "Corporate Acquisitions, Diversification, and the Firm's Life Cycle." Journal of Finance 71: 139-194.

Barnes, B. G., N. L. Harp, and D. Oler. 2014. "Evaluating the SDC Mergers and Acquisitions Database.” Financial Review 49: 793-822.

Becher, D. A., and T. L. Campbell. 2005. "Interstate Banking Deregulation and the Changing Nature of Bank Mergers." Journal of Financial Research 28: 1-20.

Boehmer, E., J. Masumeci, and A. B. Poulsen. 1991. "Event-Study Methodology under Conditions of Event-Induced Variance.” Journal of Financial Economics 30: 253-272.

Brander, J. A., and E. J. Egan. 2017. "The Winner's Curse in Acquisitions of Privately-Held Firms.” Quarterly Review of Economics and Finance 65: 249-262.

Brewer, E., and J. Jagtiani. 2013. "How Much Did Banks Pay to Become Too-Big-To-Fail and to Become Systemically Important?” Journal of Financial Services Research 43: 1-35.

Brown, S. J., and J. B. Warner. 1985. "Using Daily Stock Returns: The Case of Event Studies." Journal of Financial Economics 14: 3-31.

Capron, L., and J. C. Shen. 2007. "Acquisitions of Private vs. Public Firms: Private Information, Target Selection, and Acquirer Returns." Strategic Management Journal 28: 891-911.

Chahine, S., and A. Ismail. 2009. "Premium, Merger Fees and the Choice of Investment Banks: A Simultaneous Analysis." Quarterly Review of Economics and Finance 49: 159-177.

Chang, S. 1998. "Takeovers of Privately Held Targets, Methods of Payment, and Bidder Returns." Journal of Finance 53: 773-784.

Chemmanur, T. J., M. Ertugrul, K. Krishnan. 2019. "Is It the Investment Bank or the Investment Banker? A Study of the Role of Investment Banker Human Capital in Acquisitions." Journal of Financial and Quantitative Analysis 54: 587-627.

Cornett, M. M., and S. De. 1991. "Common Stock Returns in Corporate Takeover Bids: Evidence from Interstate Bank Mergers.” Journal of Banking and Finance 15: 273-295.

Cornett, M. M., and H. Tehranian. 1992. "Changes in Corporate Performance Associated with Bank Acquisitions.” Journal of Financial Economics 31: 211-234.

DeLong, G. L. 2001. "Stockholder Gains from Focusing versus Diversifying Bank Mergers." Journal of Financial Economics 59: 221-252.

DeLong, G. L., 2003. "The Announcement Effects of U.S. versus non-U.S. Bank Mergers: Do They Differ?" Journal of Financial Research 26: 487-500.

DeLong, G. L., and R. DeYoung. 2007. "Learning by Observing: Information Spillovers in the Execution and Valuation of Commercial Bank M\&As." Journal of Finance 62: 181216. 
Desai, A. S., and R. D. Stover. 1985. "Bank Holding Company Acquisitions, Stockholder Returns, and Regulatory Uncertainty.” Journal of Financial Research 8: 145-156.

Doukas, J., H. Gonenc, and A. Plantinga. 2014. "Private Acquisition Gains: A Contingent Claims Explanation.” European Journal of Finance 20: 1090-1113.

Eckbo, B. E., R. M. Giammarino, and R. L. Heinkel. 1990. "Asymmetric Information and the Medium of Exchange in Takeovers: Theory and Tests." Review of Financial Studies 3: 651-675.

Eckbo, B. E. 2009. "Bidding Strategies and Takeover Premiums: A Review." Journal of Corporate Finance 15: 149-178.

Faccio, M., J. J. McConnell, and D. Stolin. 2006. "Returns to Acquirers of Listed and Unlisted Targets." Journal of Financial and Quantitative Analysis 41: 197-220.

Fama, E. F., and K. R. French. 1997. "Industry Costs of Equity." Journal of Financial Economics 43: 153-193.

Fang, L. H. 2005. "Investment Bank Reputation and the Price and Quality of Underwriting Services.” Journal of Finance 60: 2729-2761.

Feito-Ruiz, I., A. I. Fernández, and S. Menéndez-Requejo. 2014. "Determinants of the Acquisition of Listed versus Unlisted Firms in Different Legal and Institutional Environments." Applied Economics 46: 2814-2832.

Finnerty, J. D., J. Jiao, and A. Yan. 2012. "Convertible Securities in Merger Transactions." Journal of Banking and Finance 36: 275-289.

Flannery, M. J., S. H. Kwan, and M. Nimalendran. 2004. "Market Evidence on the Opaqueness of Banking Firms' Assets." Journal of Financial Economics 71: 419-460.

Fuller, K., J. Netter, and M. Stegemoller. 2002. "What Do Returns to Acquiring Firms Tell Us? Evidence from Firms That Make Many Acquisitions." Journal of Finance 57: 17631793.

Graham, M., T. S. Walter, A. Yawson, and H. Zhang. 2017. "The Value-Added Role of Industry Specialist Advisors in M\&As.” Journal of Banking and Finance 81: 81-104.

Golubov, A., D. Petmezas, and N. G. Travlos. 2012. "When It Pays to Pay Your Investment Banker: New Evidence on the Role of Financial Advisors in M\&As." Journal of Finance 67: 271-311.

Golubov, A., A. Yawson, and H. Zhang. 2015. "Extraordinary Acquirers.” Journal of Financial Economics 116: 314-330.

Gupta, A., and L. Misra. 2007. "Deal Size, Bid Premium, and Gains in Bank Mergers: The Impact of Managerial Motivations." Financial Review 42: 373-400.

Gupta, A., and L. Misra. 2010. "Listing Effects and the Private Company Discount in Bank Acquisitions." In Handbook of Quantitative Finance and Risk Management, edited by C. F. Lee, A. C. Lee, and J. Lee, 1427-1443. Boston: Springer.

Hagendorff, J., and F. Vallascas. 2011. "CEO Pay Incentives and Risk-Taking: Evidence from Bank Acquisitions.” Journal of Corporate Finance 17: 1078-1095.

Hansen, R. G. 1987. "A Theory for the Choice of Exchange Medium in Mergers and Acquisitions." Journal of Business 60: 75-95. 
Heckman, J. J. 1979. "Sample Selection Bias as a Specification Error.” Econometrica 47: 153161.

Heckman, J. J., H. Ichimura, J. Smith, and P. Todd. 1998. "Characterizing Selection Bias Using Experimental Data.” Econometrica 66: 1017-1098.

Houston, J. F., and M. D. Ryngaert. 1994. "The Overall Gains from Large Bank Mergers." Journal of Banking and Finance 18: 1155-1176.

Hunter, W. C., and J. Jagtiani. 2003. "An Analysis of Advisor Choice, Fees, and Effort in Mergers and Acquisitions." Review of Financial Economics 12: 65-81.

Ismail, A. 2010. "Are Good Financial Advisors Really Good? The Performance of Investment Banks in the M\&A Market." Review of Quantitative Finance and Accounting 35: 411429.

James, C. M., and P. Wier. 1987. "Returns to Acquirers and Competition in the Acquisition Market: The Case of Banking." Journal of Political Economy 95: 355-370.

Jensen, M. C., and R. S. Ruback. 1983. "The Market for Corporate Control: The Scientific Evidence.” Journal of Financial Economics 11: 5-50.

John, K., S. Freund, D. Nguyen, and G. K. Vasudevan. 2010. "Investor Protection and CrossBorder Acquisitions of Private and Public Targets." Journal of Corporate Finance 16: 259-275.

Leland, B. R., and H. E. Pyle. 1977. "Informational Asymmetries, Financial Structure, and Financial Intermediation." Journal of Finance 32: 371-387.

Leledakis, G. N., and E. G. Pyrgiotakis. 2019. "U.S. Bank M\&As in the Post-Dodd-Frank Act Era: Do They Create Value?" Journal of Banking and Finance, Forthcoming.

Luypaert, M., and T. Van Caneghem. 2017. "Exploring the Double-Sided Effect of Information Asymmetry and Uncertainty in Mergers and Acquisitions." Financial Management 46: 873-917.

Kesner, I. F., Shapiro, D. L., and A. Sharma. 1994. "Brokering Mergers: An Agency Theory Perspective on the Role of Representatives." Academy of Management Journal 37: 703721.

Makadok, R., and J. B. Barney. 2001. "Strategic Factor Market Intelligence: An Application of Information Economics to Strategy Formulation and Competitor Intelligence." Management Science 47: 1621-1638.

Martin, K. J. 1996. "The Method of Payment in Corporate Acquisitions, Investment Opportunities, and Management Ownership.” Journal of Finance 51: 1227-1246.

Masulis, R. W., C. Wang, and F. Xie. 2007. "Corporate Governance and Acquirer Returns.” Journal of Finance 62: 1851-1889.

McLaughlin, R. M. 1992. "Does the Form of Compensation Matter?: Investment Banker Fee Contracts in Tender Offers." Journal of Financial Economics 32: 223-260.

Michel, A., I. Shaked, and Y. T. Lee. 1991. "An Evaluation of Investment Banker Acquisition Advice: The Shareholders' Perspective.” Financial Management 20: 40-49.

Mitchell, M. L., and J. H. Mulherin. 1996. "The Impact of Industry Shocks on Takeover and Restructuring Activity." Journal of Financial Economics 41: 193-229. 
Moeller, S. B., F. P. Schlingemann, and R. M. Stulz. 2004. "Firm Size and the Gains from Acquisitions." Journal of Financial Economics 73: 201-228.

Moeller, S. B., F. P. Schlingemann, and R. M. Stulz. 2007. "How Do Diversity of Opinion and Information Asymmetry Affect Acquirer Returns?" Review of Financial Studies 20: 2047-2078.

Myers, S. C., and N. S. Majluf. 1984. "Corporate Financing and Investment Decisions When Firms Have Information that Investors Do Not Have." Journal of Financial Economics 13: $187-221$.

Netter, J., M. Stegemoller, and M. B. Wintoki. 2011. "Implications of Data Screens on Merger and Acquisition Analysis: A Large Sample Study of Mergers and Acquisitions from 1992 to 2009." Review of Financial Studies 24: 2316-2357.

Officer, M. S. 2007. "The Price of Corporate Liquidity: Acquisition Discounts for Unlisted Targets.” Journal of Financial Economics 83: 571-598.

Officer, M. S., A. B. Poulsen, and M. Stegemoller. 2009. "Target-Firm Information Asymmetry and Acquirer Returns." Review of Finance 13: 467-493.

Rau, P. R. 2000. "Investment Bank Market Share, Contingent Fee Payments, and the Performance of Acquiring Firms." Journal of Financial Economics 56: 293-324.

Reuer, J. J., and R. Ragozzino. 2008. "Adverse Selection and M\&A Design: The Roles of Alliances and IPOs." Journal of Economic Behavior and Organization 66: 195-212.

Schipper, K., and R. Thompson. 1983. "Evidence on the Capitalized Value of Merger Activity for Acquiring Firms." Journal of Financial Economics 11: 85-119.

Servaes, H., and M. Zenner. 1996. "The Role of Investment Banks in Acquisitions." Review of Financial Studies 9: 787-815.

Tanna, S., and I. Yousef. 2019. "Mergers and Acquisitions: Implications for Acquirers' Market Risk.” Managerial Finance 45: 545-562.

Travlos, N. G. 1987. "Corporate Takeover Bids, Methods of Payment, and Bidding Firms' Stock Returns.” Journal of Finance 42: 943-963.

White, H. 1980. "A Heteroskedasticity-Consistent Covariance Matrix Estimator and a Direct Test for Heteroskedasticity." Econometrica 48: 817-838. 
Appendix: Variable definitions

\begin{tabular}{|c|c|}
\hline Variables & Definition \\
\hline \multicolumn{2}{|c|}{ Panel A: Deal characteristics } \\
\hline Private & $\begin{array}{l}\text { Dummy variable: } 1 \text { for acquisitions of privately held targets, and } 0 \\
\text { otherwise. }\end{array}$ \\
\hline State & $\begin{array}{l}\text { Dummy variable: } 1 \text { if both bidder and target are headquartered in the same } \\
\text { state, and } 0 \text { otherwise. }\end{array}$ \\
\hline Cash & $\begin{array}{l}\text { Dummy variable: } 1 \text { when the deal is financed purely with cash, and } 0 \\
\text { otherwise. }\end{array}$ \\
\hline Stock & $\begin{array}{l}\text { Dummy variable: } 1 \text { when the deal is financed purely with stock, and } 0 \\
\text { otherwise. }\end{array}$ \\
\hline Combo & $\begin{array}{l}\text { Dummy variable: } 1 \text { when the deal is financed with a combination of cash and } \\
\text { stock, and } 0 \text { otherwise. }\end{array}$ \\
\hline Relative size & $\begin{array}{l}\text { The transaction value divided by the market value equity of the bidding } \\
\text { company } 5 \text { days prior to the merger announcement. }\end{array}$ \\
\hline Pooling & $\begin{array}{l}\text { Dummy variable: } 1 \text { if the bidder had used the pooling accounting method to } \\
\text { incorporate the target into its books, and } 0 \text { otherwise. }\end{array}$ \\
\hline Days to completion & $\begin{array}{l}\text { The number of calendar days between the announcement date and the } \\
\text { completion date. }\end{array}$ \\
\hline Transaction value & $\begin{array}{l}\text { The total amount of consideration offered to the target firm, as reported by } \\
\text { Thomson ONE database (in million \$). }\end{array}$ \\
\hline \multicolumn{2}{|c|}{ Panel B: Bidder characteristics } \\
\hline Total assets & $\begin{array}{l}\text { The bidding firm's total assets at year-end prior to the merger announcement } \\
\text { (in million \$). }\end{array}$ \\
\hline Market value of equity & $\begin{array}{l}\text { The bidding firm's market value of equity } 5 \text { days prior to the merger } \\
\text { announcement (in million } \$ \text { ). }\end{array}$ \\
\hline Bidder size & $\begin{array}{l}\text { The natural logarithm of the bidding firm's total assets at year-end prior to } \\
\text { the merger announcement. }\end{array}$ \\
\hline ROA & $\begin{array}{l}\text { Bidding firms' return on assets (ROA) at year-end prior to the merger } \\
\text { announcement. }\end{array}$ \\
\hline Equity-to-assets & $\begin{array}{l}\text { The ratio of the bidding firms' common equity to total assets at year-end } \\
\text { prior to the merger announcement. }\end{array}$ \\
\hline Sigma & $\begin{array}{l}\text { The standard deviation of the market-adjusted residuals from } 210 \text { to } 21 \text { days } \\
\text { prior to the merger announcement. }\end{array}$ \\
\hline Occasional & $\begin{array}{l}\text { Dummy variable: } 1 \text { for bidders who completed at least } 2 \text { acquisitions over a } \\
\text { three-year window, and } 0 \text { otherwise. }\end{array}$ \\
\hline Mutual & $\begin{array}{l}\text { Dummy variable: } 1 \text { for bidders who acquired both public and private firms } \\
\text { during our examination period, and } 0 \text { otherwise. }\end{array}$ \\
\hline \multicolumn{2}{|c|}{ Panel C: Financial advisor } \\
\hline In-house & $\begin{array}{l}\text { Dummy variable: } 1 \text { if the bidding firm had not employed any financial } \\
\text { advisor, and } 0 \text { otherwise. }\end{array}$ \\
\hline Advisors & $\begin{array}{l}\text { Dummy variable: } 1 \text { if the bidding firm had employed at least one financial } \\
\text { advisor, and } 0 \text { otherwise. }\end{array}$ \\
\hline Top-tier & $\begin{array}{l}\text { Dummy variable: } 1 \text { for financial advisors that belong to the top-tier group, } \\
\text { and } 0 \text { otherwise. }\end{array}$ \\
\hline Non-top-tier & $\begin{array}{l}\text { Dummy variable: } 1 \text { for financial advisors that belong to the non-top-tier } \\
\text { group, and } 0 \text { otherwise. }\end{array}$ \\
\hline
\end{tabular}




\section{Table 1}

\section{Merger size by announcement year and target firm's listing status}

This table contains means for the total value of consideration paid by the bidder, excluding fees and expenses, segmented by year and target firm's listing status. All values are adjusted for inflation (in 2015 million \$). The sample consists of completed M\&As by U.S. banking firms, with initial bids announced between January 1, 1984 and December 31, 2015. Bidders are commercial banks with a three-digit primary SIC code equal to 602, or bank holding companies with a four-digit primary SIC code equal to 6712. Targets are comprised of publicly traded or privately held firms. Our final sample consists of 2,008 mergers, where 790 of the targets were listed firms, and 1,218 were private firms. Merger data are collected from Thomson ONE database.

\begin{tabular}{|c|c|c|c|c|c|c|c|c|c|}
\hline & Public & & Private & & & Public & & Private & \\
\hline Year & Mean & $\mathrm{N}$ & Mean & $\mathrm{N}$ & Year & Mean & $\mathrm{N}$ & Mean & $\mathrm{N}$ \\
\hline 1984 & 429.613 & 3 & 47.851 & 24 & 2000 & $1,972.670$ & 38 & 47.626 & 32 \\
\hline 1985 & 756.003 & 8 & 90.589 & 10 & 2001 & 872.118 & 28 & 56.250 & 41 \\
\hline 1986 & 990.255 & 10 & 92.047 & 31 & 2002 & 612.720 & 17 & 39.503 & 25 \\
\hline 1987 & $1,067.290$ & 16 & 64.141 & 33 & 2003 & $2,279.310$ & 35 & 54.819 & 43 \\
\hline 1988 & 529.703 & 6 & 61.128 & 17 & 2004 & $3,092.060$ & 42 & 64.876 & 48 \\
\hline 1989 & 549.955 & 18 & 39.801 & 32 & 2005 & $2,643.280$ & 22 & 146.115 & 61 \\
\hline 1990 & 64.556 & 8 & 74.228 & 23 & 2006 & $3,390.290$ & 23 & 70.395 & 44 \\
\hline 1991 & $1,219.650$ & 25 & 38.740 & 23 & 2007 & 746.984 & 27 & 90.926 & 32 \\
\hline 1992 & 437.778 & 32 & 97.507 & 33 & 2008 & $5,225.920$ & 16 & 127.439 & 7 \\
\hline 1993 & 420.435 & 42 & 54.932 & 77 & 2009 & 113.747 & 5 & 10.936 & 3 \\
\hline 1994 & 330.703 & 50 & 53.985 & 99 & 2010 & 403.162 & 12 & 18.590 & 4 \\
\hline 1995 & $1,486.200$ & 50 & 29.615 & 63 & 2011 & 170.743 & 8 & 35.319 & 10 \\
\hline 1996 & 714.209 & 34 & 58.584 & 66 & 2012 & 419.317 & 16 & 74.815 & 15 \\
\hline 1997 & $2,525.900$ & 48 & 83.744 & 90 & 2013 & 339.411 & 18 & 103.108 & 25 \\
\hline 1998 & $3,892.700$ & 46 & 76.029 & 88 & 2014 & 254.808 & 24 & 64.390 & 37 \\
\hline 1999 & $1,057.700$ & 45 & 57.812 & 47 & 2015 & 602.002 & 18 & 63.555 & 35 \\
\hline
\end{tabular}




\section{Table 2}

\section{Merger Activity by target firm's}

This table reports, by industry of the target firm, the fraction of sample firms that were acquired from 1984 to 2015. Bidders are commercial banks with a three-digit primary SIC code equal to 602, or bank holding companies with a four-digit primary SIC code equal to 6712. Targets are comprised of publicly traded or privately held firms. Target industry data are organized following Fama and French (1997) 48-industry classifications, using four-digit Primary SIC codes. Merger data are obtained from Thomson ONE database.

\begin{tabular}{llll}
\hline Target Industry & All & Public & Private \\
\hline Personal Services & 1 & 1 & 0 \\
Business Services & 20 & 5 & 15 \\
Banking & 1,808 & 730 & 1,078 \\
Insurance & 17 & 0 & 17 \\
Real Estate & 2 & 0 & 2 \\
Trading & 160 & 54 & 106 \\
\hline Total & 2,008 & 790 & 1,218 \\
\hline
\end{tabular}




\section{Table 3}

\section{Summary statistics by target firm's listing status}

This table summarizes means and medians (in brackets) for all M\&As of our sample, segmented by the target firm's listing status. The sample consists of completed M\&As by U.S. banking firms, with initial bids announced between January 1, 1984 and December 31, 2015. Bidders are commercial banks with a three-digit primary SIC code equal to 602, or bank holding companies with a four-digit primary SIC code equal to 6712. Targets are comprised of publicly traded or privately held firms. Panel A displays statistics for bidder-specific variables. Panel B details statistics for deal-specific variables. All variables are defined in the Appendix. Significance for differences in means is based on the $t$-test, assuming unequal variances. Significance for differences in medians is based on the Mann-Whitney test. Significance for differences in proportions is based on the Chi-square test. The symbols $* *$, and $* * *$ denote statistical significance at the 0.05 and 0.01 levels, respectively, using a 2 -tail test.

\begin{tabular}{|c|c|c|c|c|}
\hline & All & Public & Private & Private - Public \\
\hline Panel A: Bidder characteristics & $(1)$ & $(2)$ & (3) & $(4)$ \\
\hline \multirow[t]{2}{*}{ Total assets (million \$) } & $24,768.880$ & $42,977.450$ & $12,985.730$ & $-29,991.720 * * *$ \\
\hline & {$[4,811.477]$} & {$[9,511.236]$} & {$[3,281.887]$} & {$[-6,229.349] * * *$} \\
\hline \multirow[t]{2}{*}{ Market value of equity (million \$) } & $5,653.007$ & $9,965.419$ & $2,855.958$ & $-7,109.461 * * *$ \\
\hline & {$[1,032.955]$} & {$[2,129.237]$} & [707.200] & {$[-1,422.037] * * *$} \\
\hline \multirow[t]{2}{*}{ ROA } & 1.058 & 1.036 & 1.073 & 0.037 \\
\hline & [1.049] & [1.061] & [1.041] & {$[-0.020]$} \\
\hline \multirow[t]{2}{*}{ Equity-to-assets } & 0.087 & 0.088 & 0.087 & -0.001 \\
\hline & {$[0.083]$} & {$[0.082]$} & {$[0.083]$} & {$[0.001]$} \\
\hline \multirow[t]{2}{*}{ Sigma } & 0.016 & 0.015 & 0.017 & $0.002 * * *$ \\
\hline & {$[0.015]$} & {$[0.014]$} & {$[0.015]$} & {$[0.001]^{* * *}$} \\
\hline \multicolumn{5}{|l|}{ Panel B: Deal characteristics } \\
\hline \multirow[t]{2}{*}{ Transaction value (million \$) } & 623.141 & $1,479.740$ & 67.547 & $-1,412.193 * * *$ \\
\hline & {$[59.176]$} & {$[203.706]$} & [32.570] & {$[-171.136]^{* * *}$} \\
\hline \multirow[t]{2}{*}{ Relative Size } & 0.226 & 0.351 & 0.145 & $-0.206^{* * *}$ \\
\hline & {$[0.100]$} & {$[0.166]$} & {$[0.071]$} & {$[-0.095] * * *$} \\
\hline \multirow[t]{2}{*}{ Days to completion } & 174.279 & 191.843 & 162.887 & $-28.956 * * *$ \\
\hline & {$[162.500]$} & {$[175.000]$} & {$[151.000]$} & {$[-24.000]^{* * *}$} \\
\hline$\%$ of cash deals & 21.32 & 11.39 & 27.75 & $16.36 * * *$ \\
\hline$\%$ of stock deals & 51.89 & 59.11 & 47.21 & $-11.90 * * *$ \\
\hline$\%$ of combo deals & 26.79 & 29.50 & 25.04 & $-4.46 * *$ \\
\hline$\%$ same state deals & 49.50 & 45.44 & 52.13 & $6.69 * * *$ \\
\hline$\%$ pooling method & 23.31 & 27.97 & 20.28 & $-7.69 * * *$ \\
\hline$\%$ single bidders & 98.86 & 98.10 & 99.92 & $1.82 * * *$ \\
\hline$\%$ financial advisor used & 80.98 & 88.70 & 71.56 & $-17.14 * * *$ \\
\hline$\%$ top-tier & 29.02 & 38.41 & 14.83 & $-23.58 * * *$ \\
\hline
\end{tabular}




\section{Table 4}

\section{Bidder cumulative abnormal returns around the announcement date}

This table illustrates the bidder announcement cumulative abnormal returns. The sample consists of completed M\&As by U.S. banking firms, with initial bids announced between January 1, 1984 and December 31, 2015. Bidders are commercial banks with a three-digit primary SIC code equal to 602, or bank holding companies with a four-digit primary SIC code equal to 6712. Targets are comprised of publicly traded or privately held firms. Abnormal returns are estimated using the market adjusted returns model for a five-day event window centered on the announcement date $(-2,+2)$. In Panel $\mathrm{A}$, we report results for the entire sample. In Panel $\mathrm{B}$, results are segmented according to the method of payment. In Panel C, results are segmented based on whether the bidder has used a financial advisor or not. Number of observations is below the reported CARs. Significance for CARs is based on the standardized cross-sectional test. Significance for the mean differences in CARs between private and public offers is based on the $t$-test assuming unequal variances. The symbols $*$, **, and $* * *$ denote statistical significance at the $0.10,0.05$ and 0.01 levels, respectively, using a 2-tail test.

\begin{tabular}{|c|c|c|c|c|}
\hline Panel A: Full sample & All & Public & Private & Private - Public \\
\hline \multirow[t]{2}{*}{ All bids } & $-0.22 \% * * *$ & $-1.45 \% * * *$ & $0.57 \% * * *$ & \multirow[t]{2}{*}{$2.02 \% * * *$} \\
\hline & 2,008 & 790 & 1,218 & \\
\hline Panel B: Method of payment & All & Public & Private & Private - Public \\
\hline \multirow[t]{2}{*}{ Cash } & $0.43 \%$ & $-0.18 \%$ & $0.60 \% * *$ & \multirow[t]{2}{*}{$0.78 \% *$} \\
\hline & 428 & 90 & 338 & \\
\hline \multirow[t]{2}{*}{ Stock } & $-0.41 \% * * *$ & $-1.61 \% * * *$ & $0.56 \% * *$ & \multirow[t]{2}{*}{$2.17 \% * * *$} \\
\hline & 1,042 & 467 & 575 & \\
\hline \multirow[t]{2}{*}{ Combo } & $-0.38 \% * * *$ & $-1.63 \% * * *$ & $0.57 \% * *$ & \multirow[t]{2}{*}{$2.20 \% * * *$} \\
\hline & 538 & 233 & 305 & \\
\hline Panel C: Financial advisor use & All & Public & Private & Private - Public \\
\hline \multirow[t]{2}{*}{ In-house } & $-0.59 \% * *$ & $-0.56 \%$ & $-0.61 \% *$ & \multirow[t]{2}{*}{-0.05} \\
\hline & 187 & 61 & 126 & \\
\hline \multirow[t]{2}{*}{ Advisors } & $-0.56 \% * * *$ & $-1.90 \% * * *$ & $1.47 \% * * *$ & \multirow[t]{2}{*}{$3.37 \% * * *$} \\
\hline & 796 & 479 & 317 & \\
\hline
\end{tabular}




\section{Table 5}

Regression analysis on bidder CARs: Public vs private firms

This table reports the OLS regression results of the bidder's five-day CARs for a sample of completed M\&As by U.S. banking firms, with initial bids announced between January 1, 1984 and December 31, 2015. Models 1 and 2 report results for the entire sample, models 3 and 4 report results for the subsample of public offers and models 5 and 6 report results for the subsample of private offers. All independent variables are defined in the Appendix. All continuous variables are winsorized at $1 \%$ and $99 \%$ level. Significance is based on White (1980) heteroscedasticity consistent standard errors. The t-statistics are reported in parentheses. The symbols *, **, and $* * *$ denote statistical significance at the $0.10,0.05$ and 0.01 levels, respectively, using a 2-tail test.

\begin{tabular}{|c|c|c|c|c|c|c|}
\hline \multirow[b]{2}{*}{ Variables } & \multicolumn{2}{|c|}{ Full sample } & \multicolumn{2}{|c|}{ Public } & \multicolumn{2}{|c|}{ Private } \\
\hline & (1) & (2) & (3) & (4) & (5) & (6) \\
\hline \multirow{2}{*}{ Constant } & -0.014 & -0.023 & -0.021 & -0.018 & 0.000 & -0.024 \\
\hline & $(-1.08)$ & $(-0.96)$ & $(-0.91)$ & $(-0.56)$ & $(0.03)$ & $(-0.92)$ \\
\hline \multirow[t]{2}{*}{ Private } & $0.015 * * *$ & $0.020 * * *$ & & & & \\
\hline & $(6.84)$ & (6.06) & & & & \\
\hline \multirow[t]{2}{*}{ State } & 0.001 & 0.005 & 0.001 & 0.005 & 0.001 & 0.006 \\
\hline & $(0.30)$ & (1.63) & $(0.25)$ & (1.10) & $(0.35)$ & (1.39) \\
\hline \multirow[t]{2}{*}{ Cash } & $0.005 *$ & 0.006 & $0.011 * *$ & 0.010 & 0.003 & -0.000 \\
\hline & (1.94) & (1.42) & (2.12) & (1.30) & (1.08) & $(-0.09)$ \\
\hline \multirow[t]{2}{*}{ Stock } & $0.007 * *$ & $0.008 *$ & $0.008^{*}$ & $0.010 *$ & 0.004 & -0.001 \\
\hline & $(2.49)$ & (1.87) & (1.88) & $(1.75)$ & (1.29) & $(-0.25)$ \\
\hline \multirow[t]{2}{*}{ Bidder size } & -0.001 & -0.001 & -0.001 & -0.001 & -0.001 & -0.001 \\
\hline & $(-1.41)$ & $(-0.58)$ & $(-0.52)$ & $(-0.33)$ & $(-0.91)$ & $(-0.37)$ \\
\hline \multirow{2}{*}{ Relative size } & $-0.010 * *$ & -0.007 & $-0.014 * *$ & -0.006 & 0.009 & 0.005 \\
\hline & $(-2.15)$ & $(-1.17)$ & $(-2.34)$ & $(-0.90)$ & $(0.90)$ & (0.39) \\
\hline \multirow[t]{2}{*}{ ROA } & 0.001 & 0.000 & 0.001 & -0.005 & 0.002 & -0.001 \\
\hline & $(0.45)$ & $(0.07)$ & $(0.22)$ & $(-0.95)$ & $(0.38)$ & $(-0.11)$ \\
\hline \multirow[t]{2}{*}{ Equity-to-assets } & 0.030 & 0.031 & 0.027 & 0.010 & 0.029 & 0.108 \\
\hline & $(0.58)$ & $(0.47)$ & $(0.31)$ & $(0.10)$ & $(0.42)$ & (1.27) \\
\hline \multirow[t]{2}{*}{ Sigma } & $0.578 * * *$ & 0.332 & 0.583 & 0.117 & $0.465^{*}$ & 0.257 \\
\hline & $(2.59)$ & (1.00) & (1.37) & $(0.20)$ & $(1.73)$ & $(0.65)$ \\
\hline \multirow[t]{2}{*}{ Pooling } & $-0.009 * * *$ & -0.006 & $-0.016 * * *$ & $-0.018 * * *$ & -0.003 & 0.000 \\
\hline & $(-3.39)$ & $(-1.25)$ & $(-3.68)$ & $(-3.00)$ & $(-0.96)$ & $(0.01)$ \\
\hline \multirow[t]{2}{*}{ Days to completion } & 0.000 & 0.000 & 0.000 & -0.000 & -0.000 & 0.000 \\
\hline & $(0.67)$ & $(0.44)$ & $(0.66)$ & $(-0.10)$ & $(-0.20)$ & (1.37) \\
\hline \multirow[t]{2}{*}{ Occasional } & 0.002 & 0.006 & 0.003 & 0.004 & 0.001 & 0.007 \\
\hline & $(0.66)$ & $(1.52)$ & $(0.67)$ & (0.69) & $(0.27)$ & (1.47) \\
\hline \multirow[t]{2}{*}{ Mutual } & $-0.004 *$ & -0.002 & 0.000 & 0.003 & -0.005 & -0.002 \\
\hline & $(-1.79)$ & $(-0.67)$ & $(0.12)$ & $(0.58)$ & $(-1.64)$ & $(-0.37)$ \\
\hline \multirow[t]{2}{*}{ Advisors } & & 0.000 & & $-0.017 * *$ & & $0.019 * * *$ \\
\hline & & $(0.05)$ & & $(-2.39)$ & & $(3.69)$ \\
\hline \multirow[t]{2}{*}{ Top-tier } & & -0.002 & & 0.002 & & -0.008 \\
\hline & & $(-0.41)$ & & $(0.38)$ & & $(-1.32)$ \\
\hline Year FE & Yes & Yes & Yes & Yes & Yes & Yes \\
\hline $\mathrm{N}$ & 2,008 & 983 & 790 & 540 & 1,218 & 443 \\
\hline Adjusted $\mathrm{R}^{2}$ & 0.107 & 0.131 & 0.069 & 0.065 & 0.062 & 0.114 \\
\hline
\end{tabular}




\section{Table 6}

\section{Regression analysis with bidder fixed effects on bidder CARs}

This table reports the fixed effects regression results of the bidder's five-day CARs for a sample of completed M\&As by U.S. banking firms, with initial bids announced between January 1, 1984 and December 31, 2015. All independent variables are defined in the Appendix. All continuous variables are winsorized at $1 \%$ and $99 \%$ level. Significance is based on White (1980) heteroscedasticity consistent standard errors. The t-statistics are reported in parentheses. The symbols *,**, and *** denote statistical significance at the $0.10,0.05$ and 0.01 levels, respectively, using a 2-tail test.

\begin{tabular}{|c|c|c|c|c|}
\hline \multirow[b]{2}{*}{ Variables } & \multicolumn{2}{|c|}{ Full sample } & \multirow{2}{*}{$\frac{\text { Advisor use }}{(3)}$} & \multirow{2}{*}{$\frac{\text { Advisor reputation }}{(4)}$} \\
\hline & $(1)$ & (2) & & \\
\hline \multirow[t]{2}{*}{ Constant } & -0.022 & 0.030 & -0.018 & 0.011 \\
\hline & $(-0.83)$ & $(0.55)$ & $(-0.78)$ & $(0.18)$ \\
\hline \multirow[t]{2}{*}{ Private } & $0.008 * * *$ & $0.009 * *$ & & \\
\hline & $(3.26)$ & (1.97) & & \\
\hline \multirow[t]{2}{*}{ State } & -0.001 & 0.003 & 0.005 & 0.002 \\
\hline & $(-0.24)$ & $(0.71)$ & $(1.52)$ & $(0.31)$ \\
\hline \multirow[t]{2}{*}{ Cash } & $0.010 * * *$ & $0.014 * *$ & $0.014 * *$ & $0.015^{*}$ \\
\hline & $(3.33)$ & $(2.15)$ & $(2.09)$ & (1.89) \\
\hline \multirow[t]{2}{*}{ Stock } & $0.008 * * *$ & 0.010 & 0.010 & 0.010 \\
\hline & $(2.81)$ & (1.54) & $(1.55)$ & $(1.36)$ \\
\hline \multirow[t]{2}{*}{ Bidder size } & 0.002 & -0.001 & -0.001 & -0.001 \\
\hline & $(0.56)$ & $(-0.15)$ & $(-0.58)$ & $(-0.09)$ \\
\hline \multirow[t]{2}{*}{ Relative size } & $-0.018 * * *$ & $-0.018 * *$ & -0.006 & $-0.018 *$ \\
\hline & $(-3.17)$ & $(-2.17)$ & $(-1.02)$ & $(-1.96)$ \\
\hline \multirow[t]{2}{*}{ ROA } & -0.004 & -0.009 & -0.000 & -0.015 \\
\hline & $(-0.81)$ & $(-1.02)$ & $(-0.00)$ & $(-1.54)$ \\
\hline \multirow[t]{2}{*}{ Equity-to-assets } & 0.074 & 0.016 & 0.031 & -0.013 \\
\hline & $(0.86)$ & $(0.11)$ & $(0.47)$ & $(-0.08)$ \\
\hline \multirow[t]{2}{*}{ Sigma } & $0.620^{*}$ & 0.171 & 0.425 & 0.753 \\
\hline & $(1.87)$ & $(0.27)$ & (1.29) & $(0.96)$ \\
\hline \multirow{2}{*}{ Pooling } & $-0.010 * * *$ & -0.005 & -0.005 & -0.010 \\
\hline & $(-3.25)$ & $(-0.83)$ & $(-1.19)$ & $(-1.21)$ \\
\hline \multirow[t]{2}{*}{ Days to completion } & 0.000 & 0.000 & 0.000 & 0.000 \\
\hline & $(0.27)$ & $(0.05)$ & $(0.71)$ & $(1.23)$ \\
\hline \multirow[t]{2}{*}{ Occasional } & 0.005 & $0.017 * * *$ & $0.006^{*}$ & $0.018 * * *$ \\
\hline & $(1.54)$ & $(2.82)$ & $(1.69)$ & $(2.73)$ \\
\hline \multirow[t]{2}{*}{ Mutual } & -0.005 & -0.003 & -0.002 & -0.008 \\
\hline & $(-1.57)$ & $(-0.48)$ & $(-0.44)$ & $(-0.98)$ \\
\hline \multirow[t]{2}{*}{ Advisors } & & -0.003 & & \\
\hline & & $(-0.43)$ & & \\
\hline \multirow[t]{2}{*}{ Top-tier } & & 0.002 & & \\
\hline & & $(0.30)$ & & \\
\hline \multirow[t]{2}{*}{ Private $\times$ Advisors } & & & $0.010 * *$ & \\
\hline & & & $(2.11)$ & \\
\hline \multirow[t]{2}{*}{ Private $\times$ In-house } & & & -0.001 & \\
\hline & & & $(-0.18)$ & \\
\hline Public $\times$ Advisors & & & $-0.012 * *$ & \\
\hline & & & $(-2.33)$ & \\
\hline Private $\times$ Top-tier & & & & 0.010 \\
\hline & & & & $(1.03)$ \\
\hline Private $\times$ Non-top-tier & & & & $0.014 *$ \\
\hline & & & & $(1.88)$ \\
\hline Public $\times$ Top-tier & & & & 0.002 \\
\hline & & & & $(0.22)$ \\
\hline Year FE & Yes & Yes & Yes & Yes \\
\hline Bidder FE & Yes & Yes & Yes & Yes \\
\hline $\mathrm{N}$ & 2,008 & 983 & 983 & 796 \\
\hline Adjusted $\mathrm{R}^{2}$ & 0.221 & 0.242 & 0.245 & 0.289 \\
\hline
\end{tabular}




\section{Table 7}

\section{CARs based on propensity score matching}

This table illustrates CARs based on propensity scores estimated (PSM) from a probit model. The sample consists of completed M\&As by U.S. banking firms, with initial bids announced between January 1, 1984 and December 31,2015 . In each model, the dependent variable is a dummy variable that equals 1 for private offers, and 0 for public offers. Panel A reports the results of the probit model for the entire sample of 2,008 deals, and for the subsample of 983 deals where information on financial advisor were available on Thomson ONE. Heteroscedasticity-robust $t$-statistics are reported in parentheses. All independent variables are defined in the Appendix. Panel B reports the average treatment effect on the treated (ATT) for each sample. We report PSM results using the closest-neighbor approach. Standard errors for the ATTs are the heteroscedasticity-consistent standard errors outlined in Abadie and Imbens (2006). The symbols ***, and *** denote statistical significance at the $0.10,0.05$ and 0.01 levels, respectively, using a 2-tail test.

\begin{tabular}{|c|c|c|}
\hline Panel A: Probit models & & \\
\hline Variables & (1) & (2) \\
\hline Constant & $\begin{array}{c}5.516 * * * \\
(14.96)\end{array}$ & $\begin{array}{c}5.651 * * * \\
(10.09)\end{array}$ \\
\hline State & $\begin{array}{c}-0.147 * * \\
(-2.03)\end{array}$ & $\begin{array}{c}-0.369 * * * \\
(-3.50)\end{array}$ \\
\hline Cash & $\begin{array}{c}0.510 * * * \\
(4.82)\end{array}$ & $\begin{array}{c}0.497 * * * \\
(3.23)\end{array}$ \\
\hline Stock & $\begin{array}{l}0.123 \\
(1.43)\end{array}$ & $\begin{array}{l}-0.095 \\
(-0.77)\end{array}$ \\
\hline Bidder size & $\begin{array}{c}-0.499 * * * \\
(-16.12)\end{array}$ & $\begin{array}{c}-0.511 * * * \\
(-10.41)\end{array}$ \\
\hline Relative size & $\begin{array}{c}-2.503 * * * \\
(-10.70)\end{array}$ & $\begin{array}{c}-2.032 * * * \\
(-8.42)\end{array}$ \\
\hline ROA & $\begin{array}{c}-0.195^{*} \\
(-1.96)\end{array}$ & $\begin{array}{l}-0.105 \\
(-0.81)\end{array}$ \\
\hline Sigma & $\begin{array}{l}-0.898 \\
(-0.14)\end{array}$ & $\begin{array}{l}6.000 \\
(0.73)\end{array}$ \\
\hline Pooling & $\begin{array}{c}-0.163^{*} \\
(-1.86)\end{array}$ & $\begin{array}{l}-0.050 \\
(-0.39)\end{array}$ \\
\hline Days to completion & $\begin{array}{c}-0.003 * * * \\
(-5.50)\end{array}$ & $\begin{array}{c}-0.002 * * * \\
(-2.71)\end{array}$ \\
\hline Occasional & $\begin{array}{l}0.098 \\
(1.11)\end{array}$ & $\begin{array}{l}-0.003 \\
(-0.03)\end{array}$ \\
\hline Mutual & $\begin{array}{l}0.131 \\
(1.56)\end{array}$ & $\begin{array}{l}0.027 \\
(0.24)\end{array}$ \\
\hline Advisors & & $\begin{array}{c}-0.445 * * * \\
(-3.11)\end{array}$ \\
\hline Top-tier & & $\begin{array}{l}0.056 \\
(0.40)\end{array}$ \\
\hline $\mathrm{N}$ & 2,008 & 983 \\
\hline Pseudo $\mathrm{R}^{2}$ & 0.271 & 0.297 \\
\hline Panel B: ATTs & $(1)$ & $(2)$ \\
\hline $\begin{array}{l}\text { Private } \\
\text { Matched-Public } \\
\text { Difference }\end{array}$ & $\begin{array}{c}0.57 \% \\
-0.60 \% \\
1.17 \% * *\end{array}$ & $\begin{array}{c}0.88 \% \\
-1.23 \% \\
2.11 \% * * *\end{array}$ \\
\hline
\end{tabular}




\section{Table 8}

\section{Controlling for financial advisors: Heckman two-step procedure analysis}

This table reports the results of the Heckman (1979) two-step procedure to control for sample selection bias. The sample consists of completed M\&As by U.S. banking firms, with initial bids announced between January 1, 1984 and December 31, 2015. Models 1 and 3 report the results of the first-stage selection equation estimated by probit regressions. Models 2 and 4 report the result of the second-stage equation, where the dependent variable is the bidder's five-day CARs and the Inverse Mills ratio accounts for the nonzero mean of error terms. The dependent variable in model 1 equals 1 if the bidder has employed at least one financial advisor, and zero otherwise. The dependent variable in model 3 equals 1 if the bidder has employed a one top-tier financial advisor, and zero if it has employed a non-top tier financial advisor. All continuous variables are winsorized at $1 \%$ and $99 \%$ level. All independent variables are defined in the Appendix. Significance is based on White (1980) heteroscedasticity consistent standard errors. The t-statistics are reported in parentheses. The symbols *, **, and *** denote statistical significance at the $0.10,0.05$ and 0.01 levels, respectively, using a 2-tail test.

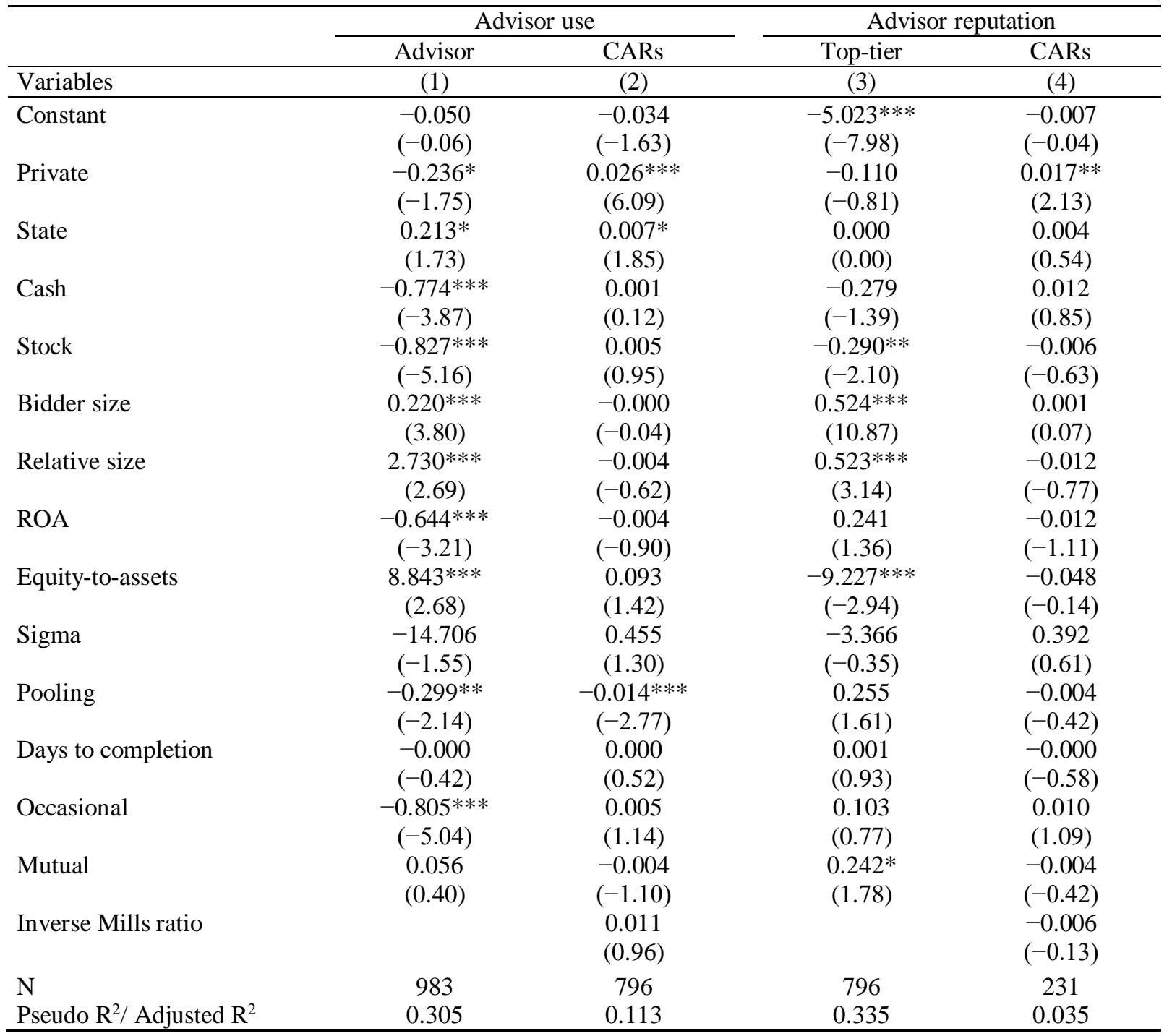




\section{Table 9}

\section{Alternative explanations for the listing effect}

This table illustrates acquisition multiples and bidder cumulative abnormal returns for a sample of completed M\&As by U.S. banking firms, with initial bids announced between January 1, 1984 and December 31, 2015. Bidders are commercial banks with a three-digit primary SIC code equal to 602, or bank holding companies with a four-digit primary SIC code equal to 6712. Targets are comprised of publicly traded or privately held firms. Abnormal returns are estimated using the market adjusted returns model. Panel A shows the acquisition multiple as reported by Thomson ONE database. The acquisition multiple is defined as the ratio of the bid amount to book value of target equity. PSM-matched multiples are calculated using the propensity score matching approach. Panels B, C, and D report CARs over several event windows. Panel B reports CARs over a $(-15,-3)$ window. Panel $\mathrm{C}$ reports CARs over a $(-2,+2)$ window around the completion date. Panel D reports bidder announcement CARs for two different sub-periods: (1) 1984-2009, and (2) 2010-2015, over a (-2, +2) window. Number of observations is below the acquisition multiples and the reported CARs. Significance for CARs is based on the standardized cross-sectional test. Significance for the mean differences in CARs between private and public offers is based on the $t$-test assuming unequal variances. The symbols $*$, and $* * *$ denote statistical significance at the 0.10 and 0.01 levels, respectively, using a 2-tail test.

\begin{tabular}{|c|c|c|c|}
\hline Panel A: Acquisition multiples & Public & Private & Difference \\
\hline \multirow[t]{2}{*}{ Raw } & 2.19 & 2.18 & -0.01 \\
\hline & 762 & 278 & \\
\hline \multirow[t]{2}{*}{ PSM-matched } & 1.86 & 2.21 & 0.35 \\
\hline & 146 & 278 & \\
\hline \multirow[t]{3}{*}{ Panel B: Run-up } & Public & Private & Difference \\
\hline & $0.10 \%$ & $0.46 \% *$ & $0.36 \%$ \\
\hline & 790 & 1,218 & \\
\hline \multirow[t]{3}{*}{ Panel C: Completion CARs } & Public & Private & Difference \\
\hline & $0.32 \% *$ & $0.10 \%$ & $-0.20 \%$ \\
\hline & 789 & 1,154 & \\
\hline Panel D: Post-2009 effect & Public & Private & Difference \\
\hline \multirow[t]{2}{*}{$1984-2009$} & $-1.62 \% * * *$ & $0.45 \% *$ & $2.07 * * *$ \\
\hline & 694 & 1,092 & \\
\hline \multirow[t]{2}{*}{$2010-2015$} & $-0.24 \%$ & $1.65 \% * * *$ & $1.89 \% * * *$ \\
\hline & 96 & 126 & \\
\hline
\end{tabular}

